\title{
ENSAIOS
}

Felipe Kern Moreira ${ }^{1}$

\section{TREATIES WITH INDIGENOUS PEOPLES IN CANADA - A NOT SO SERIOUS ESSAY2}

\author{
TRATADOS COM POVOS INDÍGENAS NO CANADÁ \\ - UM ENSAIO NÃO TÃO SÉRIO
}

\begin{abstract}
:
In contemporary Public International Law, the term 'treaties' has a precise meaning: it means "an international agreement concluded between States in written form and governed by international law" . Therefore, some may think that contemporary sovereign states understand the legal concept of a treaty is different from the historical context in which the Indigenous People of Canada negotiated those constitutive rights with the British Crown. In Canada, there are several different treaties with Indigenous Peoples regarding different sorts of rights. The case of the treaties with the First Nations of Canada is a matter of searching for fairness. In the transition from colonial North America to modern Canada, the full meaning of the treaties with the Indigenous Nations was at least subverted. This statement is not a moral judgment; it is a legal as well as political issue ipso facto.
\end{abstract}

Keywords: indigenous rights; Canada; Treaties; fishing rights

\section{RESUMO:}

No Direito Internacional Público Contemporâneo, o termo "Tratado" tem um significado preciso: significa "um acordo internacional concluído entre Estados por escrito e regido pelo direito internacional". Portanto, alguns podem pensar que os Estados soberanos contemporâneos entendem que o conceito jurídico de um Tratado é diferente do contexto histórico em que determinado povo indígena do Canadá negociou esses direitos constitutivos com a coroa britânica. No Canadá, existem vários Tratados diferentes com os povos indígenas em relação a diferentes tipos de direitos. O caso dos Tratados com as "First Nations" do Canadá é uma questão de busca de justiça. Na transição da América do Norte colonial para o Canadá moderno, o significado pleno dos Tratados com as nações indígenas foi pelo menos subvertido. Esta afirmação não é um julgamento moral; é uma questão "ipso facto" legal e política.

Palavras-chave: direitos indígenas; Canada; Tratados; direito de pesca

\section{INTRODUCTION}

When I first saw Kent Monkman's stunning painting, "Miss Chief's Wet Dream", on display at Nova Scotia Art Galery in Halifax, the work immediately reminded me of Pablo Picasso's Guernica, exhibited at the Reina Sofia Museum in Madrid. Guernica was painted as an artistic response to the aerial bombardments of the city of Gernika, in the Basque Country, Spain, during the Spanish Civil
War. For me, both paintings are disconcerting and haunting. These iconographies can be comparable in the sense of very personal and imaginative representation of a historical event, featured by the unfair prevalence of the military power, expressing through graphical intensities the upheavals of disturbing feelings, recollections, and resentments.

\footnotetext{
${ }^{1}$ Professor associado da Universidade Federal do Rio Grande-FURG. felipe.kern@furg.br, (iD) http://orcid.org/0000-0002-5084-4987

2 "This work was supported by the Ocean Frontier Institute (OFI) during an international visitor fellowship at the Marine Affairs Program, Dalhousie University."
} 


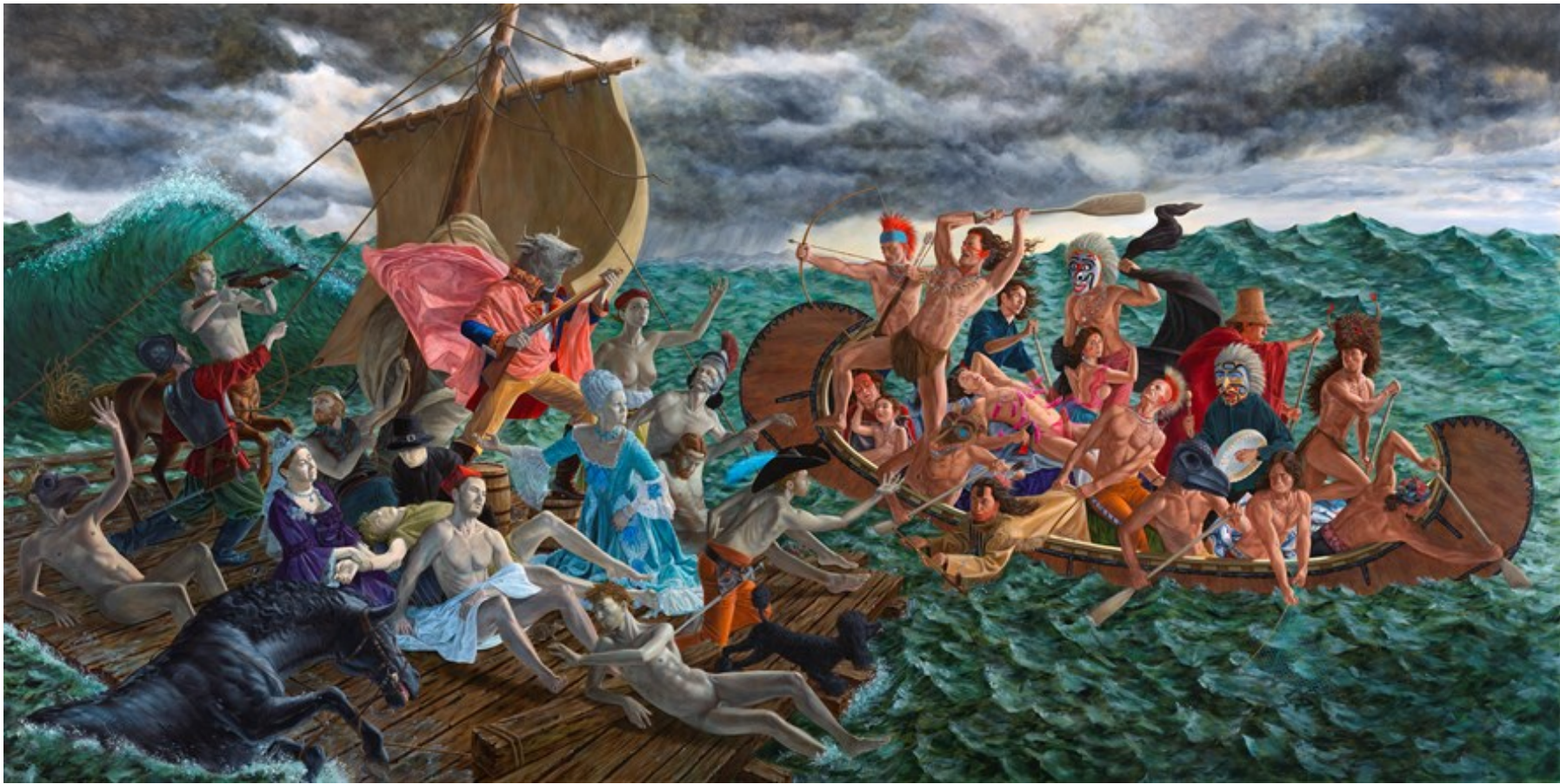

“Miss Chief's Wet Dream" (Kent Monkman, 2018) ${ }^{3}$

"Miss Chief's Wet Dream" was painted because the artist - a Canadian of Cree ancestry wanted "people to think about what the treaties were intended to be, how they were interpreted by Indigenous People, where did they go wrong?" The title of the painting refers to the alter-ego of the artist: Miss Chief Share Eagle Testickle. ${ }^{4}$ The art represents the collision of two vessels - a raft and a canoe -, representing the European settlers and the Indigenous Nations. Just like every work of art, we can find in it an enormous range of interpretations, allegories, and details regarding the contrast between the old and the new world, the profane and the sacred, the pale and the vitality. Paradoxically, the work was painted in European style. The artist mentions the influence of two famous works: 'The Raft of the Medusa' (1819) of Théodore Géricault and 'Christ on the Sea of Galilee' (1854) of Eugene Delacroix. In the same way as Monkman's painting, sometimes the contemporary critics concerning the neglect of the treaties are addressed in a very traditional argumentative way: through modern science or political discourse.

In contemporary Public International Law, the term 'Treaties' has a precise meaning: it means "an international agreement concluded between States in written form and governed by international law" ${ }^{5}$. Therefore, some may think that the way contemporary sovereign States understand the legal concept of a Treaty can vary depending on the historical context in which the Indigenous People of Canada negotiated those constitutive rights with the British Crown.

This text aims to contrast the implications of the terminologies 'Treaties' and 'nations' through a "not so serious essay" as a form ${ }^{6}$. In the territory understood today as Canada, the British Crown celebrated Treaties with the native people due to the recognition of aboriginal societies as nations and, in the legal concept, subjects of international law. The Crown and the Indians recognized themselves mutually as sovereign entities ca-

\footnotetext{
${ }^{3}$ Available at: https://www.artgalleryofnovascotia.ca/exhibitions/kent-monkmanmisschief

${ }^{4}$ Available at http://www.kentmonkman.com/biography/.

${ }^{5}$ Viena Convention on the Law of Treaties (1969), Article 2 (1), a.

${ }^{6}$ “The essay, however, does not permit its domain to be prescribed. Instead of achieving something scientifically, or creating something artistically, the effort of the essay reflects a childlike freedom that catches fire, without scruple, on what others have already done." (ADORNO et alia, 1984, 152)
} 
pable of negotiating, signing and respecting treaties. Otherwise, they - mainly the Europeans would not use this form of a formal instrument of International Law.

From colonial times to the present day, what happened to Treaties in the course of Canadian history? Maybe the understanding of the concept of 'nations' changed dramatically. The European settlers turned into modern States with some Commonwealth colonial remnants. The Indigenous People were relegated to be societies, so-called (and so forced by circumstances of the day) minorities in their territory and gradually integrated into those modern national statal units.

Centuries later, the Indigenous Peoples scattered throughout Canadian territory survived resiliently, despite the State. In the second half of the twentieth century, the leading cases Sparrow (1992) and Marshall (1999) largely rewrote the legal meaning of the Treaties. This lead to the recognition of some rights of the Treaties of 1760 and 1761 (CANADA, 1760-1761), which were a reaffirmation of the Boston Treaty of 1725 :

The Boston treaty was negotiated in Boston during the autumn of 1725 , bringing to an end three years of war between the Aboriginals (namely Abenaki, Wuastukwiuk and the Mi'kmaq) and Nova Scotia and New England. "With the fall of Louisbourg in 1758, Quebec in 1759 and Montréal in 1760, Mi'kmaq and Wuastukwiuk sakamows re-affirmed the 1725 treaty in 1760 and 1761. (WICKEN; REID, 1996, 63-65)

In the transition from colonial North America to modern Canada, the full meaning of the Treaties with the Indigenous Nations was at least subverted. This statement is not a moral judgment; it is a legal as well as political issue ipso facto. This is what this essay is about.

\section{I - INDIGENOUS PEOPLE AS NATIONS: IT MATTERS YET?}

The Treaty of Tordesillas of 1494 and the Treaty of Saragossa of 1529 may have been the first sources of international law regarding the
Amerindian domains. In the Inter Coetera Bull of 1493, Pope Alexander VI expresses the wish that the original peoples of America be dominated and converted: barbarica nationes deprimantur et ad fidem ipsam reducantur (ZIEGLER, 2007, 123). Legal historiography records that, in the 16th century, there was controversy regarding the Indigenous Peoples of America, with particular emphasis on the work of Francisco de Vitória (1483-1546), Juan de la Peña (1513-1565) and Francisco Suárez (1548 - 1617). Francisco de Vitória left his written classes (relectiones) of which two, dated 1532, refer to Indigenous Peoples: "On the discovery of the Indians" (De Indis recenter inventis) and "On the wars of Spain against the original peoples" (De iure belli Hispanorum in barbaros) (ZIEGLER, 2007, 132). He argued that Indigenous Peoples should be understood as nations and that the war against them could only be justified by a just cause (SHAW, 2003,22 ). Today we recognize the theoretical and argumentative advances on the part of late Spanish scholastic, notably regarding the right to war. Spain had maintained the war on the reason of the indigenous resistance refusal to be evangelized:

\begin{abstract}
Therefore the Indians cannot be induced by war to believe, but rather to feign belief and reception of the Christian faith, which is monstrous and a sacrilege (...) Further, the Pope cannot make war on Christians on the ground of their being fornicators or thieves or, indeed, because they are sodomites; nor can he on that ground confiscate their land and give it to other princes; were that so, there would be daily changes of kingdoms, seeing that there are many sinners in every realm. (VITÓRIA, 2015, 01-02)
\end{abstract}

For Francisco de Vitória, it was not a legitimate argument. As Hugo Grotius anticipated, with his De Mare Liberum (1609), ideas that would echo at the 1982 United Nations Convention on the Law of the Sea; Francisco de Vitória, with De Indis (1532), anticipates the International Labor Organization Convention 169 of 1989 (Indigenous and Tribal Peoples Convention).

The First Nations had their diplomatic protocols and traditions before the arrival of the Euro- 
peans. In colonial times, aboriginal peoples have historically represented themselves as sovereign nations, negotiating Treaties with the Crown (BARROS, 2014, 36). Therefore, the French and the English were compelled to establish relations with the Aboriginals as sovereign nations. These political practices included conducting wars, negotiating Treaties, and establishing trade and alliances. So "for Britain and for France, early Aboriginal policy was a foreign policy." (CANADA, 2015, 50). The Treaties that the British Crown negotiated with the Aboriginals in the second half of the XVIII Century were not different from others like the Paris Treaty of 1763 , concluding the Seven Years War, signed by representatives of Great Britain and Hanover on one side and France and Spain on the other (PALACIOS et alii, 2016). Even though the Aboriginals were not part in the Treaty of Paris, "much of the land in North America that the French ceded to Britain was, in fact, Aboriginal land." (idem, 52). Brian Slattery understands that Indigenous nations had exclusive titles to their territories at the time of European contact. So, the Treaties were negotiated on an equal basis between the settlers and the natives, which proves that modern international law is not the exclusive product of European genius (SLATTERY, 1991, 694-702). Nowadays is common-sense that the Treaties negotiated between the British and the Aboriginals were ignored by the settlers or interpreted in ways that restricted the original rights.

In December 2015, after receiving the Final Report of the Truth and Reconciliation Commission, the Canadian Prime Minister, Justin Trudeau, issued some statements. At that time, he stated that the Canadian government had a plan "to move towards a nation-to-nation relationship [with Indigenous Peoples] based on recognition, rights, respect, cooperation, and partnership." ${ }^{7}$ Remarkably, the governmental speech tries to place the Indigenous people as nations in the equivalent le- vel of the State of Canada, a sort of sovereign equality. One can argue that this is pure rhetoric. We all know that using the terminology 'nation' does not mean that the Indigenous Peoples are subjects of International law at the same level as a State or an International Organization. In terms of international law, the statement of Justin Trudeau can be understood as a part - albeit tiny - of an opinio juris or - in other terms - the subjective element of the costume as a formal source of international law ${ }^{8}$. The difficulty here is the consistency: this was a Prime Minister statement, repeated over the past few years and which may change, even though in 2019 Justin Trudeau was re-elected (AUSTEN; BILEFSKY, 2019).

\section{II - THE SUCCESSION OF STATES: THE CANADIAN CASE}

Sovereign States live in an international society characterized by the existence of shared rules and principles. When there is a transition from the essential characteristics of one sovereign State to another, there are numerous political and legal consequences for the international community. The sovereign States live in an international society characterized by the existence of shared rules and principles. When there is a transition from the essential characteristics of one sovereign State to another, there are numerous political and legal consequences for the international community. Recent examples were the independence of East Timor in 2002, and the secession and succession of the Czech Republic and Slovakia in 1993. Therefore, independence, secession, and succession may alter the characteristics of diplomatic representations and the validity of Treaties. Considering that the Treaties of 1760 and 1761 were negotiated between the British Crown and the American natives, it means that the legal responsibility regarding

\footnotetext{
Available at <https://pm.gc.ca/en/news/statements/2015/12/15/statement-prime-minister-release-final-report-truth-and-reconciliation>. Accessed on August 2019.

${ }^{8}$ About the implications of the subjective element in the formation of the international custom see ELIAS, 1995. "Traditional theories of opinio juris are problematic because it is often difficult to find clear indications that States consider a given rule or practice to be obligatory. The problem is largely one of proof. If opinio juris is described as belief or conviction, the problems involved in finding out its content are patent. (...) There are several dicta in the Nicaragua case which would suggest that opinio juris can be individual or at least confined only to a number of States, even in the context of general customary law" (ELIAS, 1995, 514 and 519)
} 
the articles of the Agreements was taken initially by the British.

Canada has a history of a gradual process of political independence of the United Kingdom. The British North America Act of 1867 passed by the UK Parliament was the first significative step towards self-governing. In 1931 Canada joined the British Commonwealth with the same sovereign status of the United Kingdom. The Canada Act of 1982, passed by the Parliament of the United Kingdom, ended the power of the British Parliament to amend the Constitution of Canada and some provisions related to "request and consent" established by the Statute of Westminster of 1931, which was a British law clarifying the powers of Canada's Parliament (BÉDARD; LAGASSÉ, 2015, 99 and 223). The British Queen is the monarch of the 16 countries of the Commonwealth. In the Canadian political-legal system, it is possible to identify the representatives of the royalty: the GovernorGeneral and the ten provincial Lieutenant Governors (BÉDARD; LAGASSÉ, 2015, 50). Each Canadian knows that this tour is called' homecoming' when a member of the Royal Family visits Canada because Canada is one of the Queen's realms.

What is the current legal validity of Treaties between the British Crown and the First Nations if we consider the succession of Canada from the colonial period to the contemporary? The A. P. Lester's detailed research on 'State Succession to Treaties in the Commonwealth' indicates that the old Dominions agreed to inherit all British Treaties as early as 1919 but makes no mention to Treaties with native peoples:

(...) the High Court of Ontario held that the change in Canada's status from colony to independent nation made by the Statute of Westminster, 1931, did not per se render invalid the 1842 Ashburton Treaty between the Imperial Government and the United States, which was intended to apply to Canada. Jenks considers that the old Dominions agreed to inherit all British treaties as early as 1919. (LESTER, 1963, 485).
In this sense, the Peace Treaties with the native nations did not receive the same attention of specialist literature like the fall of Quebec and the Treaty of Paris of 1763 (SLATTERY, 1991, 683). This question has captured my interest since I started researching on the fishing rights of the Indigenous Peoples of Canada. From that moment, I realized the artistic message of "Miss Chief's Wet Dre$\mathrm{am}^{\prime}$, it was an inspiring invitation to write this essay.

\section{III - IS A 'TREATY' JUST AN OLD- FASHIONED TERMINOLOGY FOR THE CONTRACT THAT HAS NOT BEEN FUL- FILLED?}

The Treaties guaranteed Mi'kmaq, Wolastoqiyik, and Passamaquoddy peoples the right to hunt, fish, farmland, and earn a reasonable living without British interference. The Treaty of 1761 was signed in a "Burying the Hatchet" ceremony in Halifax in which is commemorated annually on 1 October, the Treaty Day (WALLACE, 2018). These early Treaties were understood as "mere contracts to remove Indians from their lands" (COTÉ, 2001, 16). The British North America Act of 1867 and the Indian Act of 1876, represented the control over the Indians and their lands by the federal government of Canada so that any form of Indigenous right to self-government is delegated by the Canadian Parliament (COTÉ, 2001, 17).

In recent years, the essential legal reference regarding Indigenous Peoples' rights in Canada is the Constitution Act of 1982, which recognizes the existing aboriginal and Treaty rights of the aboriginal peoples of Canada. So, after 1982, the crucial legal question was to ask what was the effectiveness of that Treaty rights. In a large extent, this question was answered by the leading cases Sparrow and Marshall.

In the Sparrow case (1992), the Supreme Court recognized for the first time the Aboriginal and Treaty rights of the Constitutional Act of 1982 (CHALUPOVITSCH, 2019, 01). The Supreme Court emphasized that the Constitutional Act did 
not create Aboriginal rights since these rights already existed under common law and only to rights that already existed at the time that the Constitutional Act came into force (idem, 1-2). In the Marshall case (1999), the appellant relied on the Mi'kmaq Treaties of 1760 and 1761 (CHALUPOVITSCH, 2019, 7). One crucial decision in this judgment is that the Treaties gave the Mi'kmaq people the right to sell fish to secure "necessities", which can be considered equivalent to a "moderate livelihood". (idem, ibidem). The Marshall decision resulted in the growing involvement of Mi'kmaq First Nations in commercial fishing activities with strong opposition of non-native people (CAPISTRANO; CHARLES, 2012, 202).

There are different kinds of critics addressed to Marshall decisions, mainly related to the constraints carried by the "moderate livelihood" criteria. Some analysis understands that is the case of jurisprudence that permitted the government to infringe Aboriginal and Treaty rights (HARRIS; MILLERD, 2010, 103). David Bedford defined the Marshall decision as "emancipation as oppression" (2010), and Matthew Coon, former national chief of the Assembly of First Nations, declared that 'moderate livelihood' is "just the right to live in poverty" (STEWART, 2000, 1).

The legal perspective of considering Treaties as international agreements and Indigenous Peoples as nations has never been seriously considered in Canada. Nor the possibility for the modern Canadian State of inheriting Treaties negotiated by the Crown in the sense of a succession of States. Here we have to differentiate between the Prime Minister's speeches and what the Courts have been interpreting. The Supreme Court of Canada shifted from a conception of Treaties with First Nations to contracts between the Crown and a group of citizens (HUNTERS,
2004, 62). The alleged advantage is to consider Treaty rights as a form of constitutional rights, and so this shift was regarded as positive for Aboriginal peoples. Claire E. Hunter disagrees with this contactual approach since many Treaties were 'bad bargains' (idem, 64).

Hunter argues for the reincorporation of contractual doctrine into Treaty interpretation. This point of view avoids considering Treaties as unilateral records of conquest. It tries to capture the understanding of the unequal bargain of power (idem, 64): an unusual legal theory that seems not to have prevailed in the Canadian jurisdictional field. There is an idea of fairness in the recognition of the Treaties in the 1982 Constitutional Act and in the reasoning of the Marshall case. It seems better to recognize the rights contained in the Treaties than any recognition at all. On the one hand, Treaty rights continue to be negotiated to this day 9 . In this sense, the 1982 Constitutional Act is an essential constitutive basis of rights. On the other hand, for Indigenous Peoples, the best of rights seems to be those they had before negotiating any of the Treaties.

Is a 'Treaty' just an old-fashioned terminology for the contract that has not been fulfilled? No. A contract is a legal status sometimes given by the Canadian Supreme Court to adapt Treaties to the constitutional jurisdiction. In other judgments taken by the Supreme Court of Canada, the essence of the Treaties is kept untouchable, as the case Mikisew Cree First Nation v. Canada (2018 SCC 40) regarding the duty to 'honour of the Crown'10. In modern times, the legal nature of the Treaties became a tertio genus in the Canadian legal system, nor an international Treaty negotiated with another NationState, nor a contract between the government and a specific group of citizens.

\footnotetext{
9 "While early treaties are still recognized, in 2002 Nova Scotia's thirteen Mi'kmaq chiefs, provincial and federal governments signed an agreement to engage in tripartite discussions on outstanding issues (Tota 2002). In 2007 the three parties put in place a five-stage process to resolve issues pertaining to Mi'kmaq treaties, rights and title (NS 2007)." (VODDEN, 2009, 118)

10 "Treaties are understood to be between Indigenous groups and "the Crown." "The Crown" means Canada as a state. The Crown negotiated and signed treaties like the one with the Mikisew in 1899, and still has a duty to fulfill them today. The Crown also has other duties, based on the Aboriginal and constitutional law concept of the "honour of the Crown." This requires the Crown to act honourably toward Indigenous peoples." (Brief of the case. Available at: https://www.scc-csc.ca/case-dossier/cb/37441-eng.aspx. Accessed on August 2019).
} 


\section{IV - DREAMING OF THE CONCLUSION}

There is a taboo in modern national societies with a substantive presence of Indigenous Peoples - the taboo of not recognizing that indigenous societies are nations that will not be diluted with national multinaturalism ${ }^{11}$. In the Canadian case, there are deep structures of modern State constitutionalism that place the First Nations and the State on duty to 'honour of the Crown', which means to implement the Treaties in their authentic legal sense and historical context. Treaties are products of mutual recognition of sovereign legal capacities. In Canada, there are several different Treaties with Indigenous Peoples regarding different sorts of rights. The agreements in some Treaties are, in fact, not favourable to Indigenous Peoples and considerably limit the rights to land, hunting, and fishing. Treaties are the basis of the Canadian rights in indigenous domains even though the perspective of power circumstances places some on the other side of the mirror.

My conclusions probably are the same of those whom read this essay until these lasting lines: there is no logic as well as consequential conclusion like the result of mathematical calculus. At the end of the day - or, maybe in the case of this wet dream - at the end of this night of centuries, the case of the Treaties with the First Nations of Canada is a matter of searching for fairness. By the way, fairness is an adequate basis for a process of reconciliation. One can say that maybe there are two perspectives of justice on the legal effects of that old Treaties. The justice in this case, like the Janus Bifrons, looks in different directions: one of the Canadian State and other of the First Nations. In the legal perspective of the contracts, the contemporary interpretation of the Treaties will continue to be what always it was: an endless exercise of legal argumentation. This is not a case for the interpretation of legal norms, is a question of justice. But, what sort of justice paleface? What is justice? Justice is what we make of it: a wet dream or an arid nightmare.
REFERENCES

ADORNO. T. W; HULLOT-KENTOR, Bob; WILL, Frederic. The essay as form. New German Critique, no. 32 (Spring-Summer, 1984), pp. 151-171.

AUSTEN, Ian; BILEFSKY, Dan. Justin Trudeau's Liberal Party Weakened but Re-Elected in Canadian Election. New York Times, oct. 21, 2019. Available at https:// www.nytimes.com/2019/10/21/world/canada/electi ons-canada-results.html. Accessed on June 8, 2020.

BARROS, Priscila Ribeiro Prado. Recognizing indigenous peoples' rights: a comparative study between Brazil and Canada. Canadian Journal of Latin American and Caribbean Studies, 38:1, 2013, pp. 35-49.

BÉDARD, Michel; LAGASSÉ, Phillippe (ed.) The Crown and Parliament. Montréal (Québec): Éditions Yvon Blais, 2015.

CANADA. Treaties 1760-61. Articles of Submission and Agreement at Boston in New England by Sauguaaram als Loron Arexus Francois Xavier and Meganumbe Delegates from the Tribes of Penobscot Naridgwalk St. Johns Cape Sable and other Tribes of the Indians inhabiting within His Majesty's Territories of Nova Scotia and New England. Available at http:// caid.ca/Treaty1760_61.pdf. Acessed on June 9, 2020.

CANADA. Truth and Reconciliation Commission of Canada. Canada's Residential Schools: The History: Part 1 Origins to 1939. The Final Report of the Truth and Reconciliation Commission of Canada Volume 1. Montreal: McGill-Queen's University Press, 2015.

CAPISTRANO, Robert Charles G.; CHARLES, Anthony $T$. Indigenous rights and coastal fisheries: A framework of livelihoods, rights and equity. Ocean \& Coastal Management. Vol. 69, December 2012, pp. 200-209.

CASTRO, Eduardo Viveiros de. Cosmological Deixis and Amerindian Perspectivism. The Journal of the Royal Anthropological Institute, Vol. 4, No. 3 (Sep., 1998), pp. 469- 488.

\footnotetext{
${ }^{11}$ About multinaturalism see CASTRO, 1998.
} 
CHALUPOVITSCH, Michael. Commercial Fishing Under Aboriginal and Treaty Rights: Supreme Court of Canada Decisions. Ottawa: Library of Parliament, 2019.

COTE, Charlotte. Historical Foundations of Indian Sovereignty in Canada and the United States: A Brief Overview. American Review of Canadian Studies, 31 (1-2), 2001, pp. 15-23.

ELIAS, Olufemi. The Nature of the Subjective Element in Customary International Law. The International and Comparative Law Quarterly, Vol. 44, No. 3 (Jul., 1995), pp. 501-520.

HARRIS, Douglas C.; MILLERD, Peter. Food Fish, Commercial Fish, and Fish to Support a Moderate Livelihood: Characterizing Aboriginal and Treaty Rights to Canadian Fisheries. Arctic Review on Law and Politics 82, (2010) 1, pp. 82-107.

HUNTER, Claire E. New Justification for an Old Approach: In Defence of Characterizing First Nations Treaties as Contracts. University of Toronto Faculty of Law Review, Volume 62, Issue 1 (2004), pp. 61-83.

KOHEN, Marcelo G. (ed.). Secession: International Law perspectives. Cambridge: Cambridge University Press, 2006.

LESTER, A. P. State Succession to Treaties in the Commonwealth. The International and Comparative Law Quarterly. Vol. 12, No. 2 (Apr., 1963), pp. 475-507.

MOREIRA, Felipe Kern. Regime Internacional dos Povos Indígenas: referências teórico-descritivas. In: InterAção, v. 9, n. 1 (2018). Available at https:// periodicos.ufsm.br/interacao/article/view/33951.

Acessed on May 28, 2019.

PALACIOS, Sebastián Amaya; ZAPATA, Juan David Restrepo; GONZÁLEZ, Héctor Fernando Grajales. La frontera norte novohispana y la resistencia indígena, 1763-1785. Vegueta: Anuario de la Facultad de Geografía e Historia, 2016, Issue 16.

SHAW, Malcom N. International Law. Fifth Edition. Cambridge: Cambridge University Press, 2003.
SLATTERY, Brian. Aboriginal Sovereignty and Imperial Claims. Osgoode Hall Law Journal Vol. 29.4 (1991), pp. 681-703.

STEWART, Lyle. Matthew, Marshall and a moderate living: Canada's supreme court has ruled that native people have a right to make a "moderate living" from natural resources. Matthew Coon Come says that's just the right to live in poverty. This: Toronto, vol. 34, 3, (Nov./Dec.), 2000.

UNITED NATIONS. Viena Convention on the Law of Treaties. Done at Vienna on 23 May 1969. Entered into force on 27 January 1980. United Nations, Treaty Series, vol. 1155, 2005.

VITÓRIA, Francisco de. De Indis (1532). Available at: http://theahi.org/wp-content/uploads/2013/ 10/Francisco-de-Vitoria-on-War.pdf. Accessed on August 1st, 2015.

VODDEN, Kelly. New Spaces, Ancient Places: Collaborative Governance and Sustainable Development in Canada's Coastal Regions. Submitted in partial fulfillment of the requirements for the degree of Doctor of Philosophy. Department of Geography. Simon Fraser University. Summer, 2009.

WALLACE, Sarah Isabel. Peace and Friendship Treaties. The Canadian Encyclopedia. Historica Canada. Article published May 28, 2018. Available at https://www.thecanadianencyclopedia.ca/en/ article/peace-and-friendship-treaties. Accessed on August 2019.

WICKEN, William C.; REID, John G. An overview of the eighteenth century treaties signed between the Mi'kmaq ans Wuastukwiuk Peoples and the English Crown, 1963-1928. Report submitted to Land and Economy Royal Commission on Aboriginal Peoples (1996). Available at: http://publications.gc.ca/ collections/collection_2017/bcp-pco/Z1-1991-1-41150-eng.pdf. Accessed on August 2019.

ZIEGLER, Karl-Heinz. Völkerrechtsgeschichte. 2. Auflage. München: Verlag C.H. Beck, 2007. 